\title{
Ownership Structure, Firm Value and Investment Opportunities Set: Evidence from Mexican Firms
}

\section{Juan M. San Martin-Reyna*, Jorge A. Durán-Encalada**}

\begin{abstract}
This paper analyses the influence of ownership, board of directors, and financial leverage on companies' performance when these either face, or do not face, profitable growth opportunities. Towards that end we examined a sample of 83 listed Mexican firms during the period 2005-2011. The results confirm the relevance of debt and board of directors in terms of firm market value by showing a negative relationship between performance and both, board of directors and leverage, in the presence of growth opportunities. In contrast, the relationship between debt and performance becomes positive when firms have no profitable investment projects. The results also demonstrate that the relevance of controlling shareholders on firm value is different when firms have or not growth opportunities. Therefore, our results show that ownership structure, composition and size of board and the level of leverage play a dual role on performance (increase or decrease the firm value) and determinewhether the firms have profitable investment projects.

Keywords: debt, investment opportunities, performance, family business.
\end{abstract}

\section{Introduction}

The agency problem between shareholders and managers raised by Berle and Means (1932) as a result of dispersed shareholders in large enterprises arises when the contributors of the funds need to finance investments. Then, while assuming the business risk, the shareholders are forced to entrust supervision and direction to someone who possesses the qualifications and skills needed to perform these functions. If the shareholders were to have complete information on investment opportunities presented to the organization and available to company managers, they would be able to design full-blown contracts that do not give room for the discretion of managers. But this is not likely and the actions of management and investment opportunities are not perfectly observable by the owners, as a result, managers can

* Dr. Juan M. San Martin-Reyna, Family Business Research Centre - Universidad de las Américas Puebla, juanm.sanmartin@udlap.mx.

** Dr. Jorge A. Durán-Encalada, Family Business Research Centre - Universidad de las Américas Puebla, jorgea.duran@udlap.mx. 
engage in an opposite conduct to the owners' interests. In other words, managers may have incentives to expropriate the company's profits through projects that benefit them but can adversely impact shareholders (Jensen and Meckling, 1976; Fama and Jensen, 1983).

A conflict of interests has a potential agency cost such as management decisions that do not maximize shareholders' interests. Managers may handle reported earnings to justify their actions and this can lead to an agency cost where investors make nonoptimal investment decisions from reported earnings. In a situation where a company has a high free cash flow, the manager may be engaged in earnings management that leads to a less than satisfactory performance of the company. This relation can be explained by using agency theory. In this contractual context, characterized by the conflict of interests between shareholders and managers, corporate governance involves the design of a series of mechanisms that reconcile the interests of shareholders and managers (Fama and Jensen, 1983; Hart, 1995; Mayer, 1996), thus avoiding the management that seeks to maximize its utility function at the expense of shareholder's wealth.

A growing body of literature has shown how growth opportunities open to the firm influence the relation between performance and financial decisions (Smith and Watts, 1992; McConnell and Servaes, 1995; Lang et al., 1996; De Andres et al., 2005; Bukit and Iskandar; 2009; Chen and Liu 2010). However, much less is known about how this relationship is influenced by ownership structure, particularly family ownership. This is an important issue because a new conflict of interests can arise between the controlling majority and the minority shareholders. The fundamental agency problem for listed companies in emerging markets is not a conflict of interest between outside investors and managers, as argued by Berle and Means (1932), but a conflict of interest between controlling shareholders and minority shareholders (Shleifer and Vishny, 1997).

Evidence shows that family businesses retain advantages and that the superior performance of family ownership is even more evident in emerging markets where they are viewed as the "engines" of the economy (Whyte, 1996). Large family controlled groups are dynamic and versatile, and they account for a significant proportion of gross national product in high-growth emerging markets (Carney, 2005; Claessens et al., 2002). In Mexico, a majority of firms, as in most developing countries, are considered family businesses. Nevertheless, very few studies refer to Mexican family businesses, so it is important to have more research that focuses on them.

Under the agency theory approach, our study aims to analyze if the measures set by shareholders to control the managerial team through internal mechanisms work, and whether these measures have a positive or negative impact on performance when managers face options to increase firms' profits. These growth options consider the use of cash flows available for the managers to invest in projects with positive net present value, once they have covered all short-term liabilities.

As a consequence, this study examines if in the presence of growth opportunities shareholders operate with the same control mechanisms as when there is an absence 
of growth opportunities. We applied this theoretical framework to a sample of large Mexican firms publicly traded in capital markets for the period 2005-2011.

This study follows the research made by Andres et al. (2000), Myers (1977), Jensen (1986), Morck et al. (1988), Stulz (1990), Smith and Watts (1992), Lasfer (1995), and draws heavily on the works of McConnell and Servaes (1995) and De Andres et al. (2005). These last authors are among those which propose to sort out companies according to their growth opportunities using variables like price earnings ratio (PER), the market-to-book ratio (MBR) (Smith and Watts, 1992; Lasfer, 1995; McConnell and Servaes, 1995), or sales rate of growth (SRGR) (McConnell and Servaes, 1995; La Porta et al., 2000, De Andres et al., 2005). However, the present study deviates from that research by focusing not only on debt influence, but also on family ownership and board variables effects in order to expand the analysis framework.

The results show that ownership, leverage, and board of directors variables affect firm value, and that the type of influence depends on the presence or absence of investment opportunities. Family ownership, composition and size of board of directors, and the level of financial leverage play a dual role: they increase the performance when there are not investments projects, but have negative impact in the presence of growth opportunities. A problem of wealth expropriation arises between majority and minority shareholders in firms with greater growth opportunities. However, ownership concentration, debt, and board act as disciplinary mechanisms only in firms with an absence of growth opportunities.

To accomplish its aims the paper is divided into five sections, starting with this introduction. Section two examines previous research and presents the theoretical foundations of the work. In the third section the methodological issues include a description of the sample, variables, and the regression model applied. Section fourth presents the results as well as some comments and discussion. The final section, draws some conclusions from the results and points out to some future research directions.

\section{Literature review}

\section{Agency theory}

The importance of corporate mechanisms and its implications for the company has been widely studied in economic theory. One of the main theories that study formally this relationship is the agency theory, which establishes the existence of interest conflict between owners and managers (principal and agent problem). Ross (1973) defines an agency relationship as a link between two or more parts, one designated as the "agent", acting as the representative of the other, named the "principal". However, monitoring and controlling the agent is expensive as the agent can engage in decision making and behaviors that may be inconsistent with maximizing shareholder wealth (Daily et al., 2003). Thus, owners have as their main objective profits maximization, but due to incomplete information they cannot make contracts that allow them 
to eliminate the managerial discretion (Jensen and Meckling, 1976). It also creates information asymmetries that make it possible for agents to engage in activities that, if left unchecked, would threaten firm performance and may ultimately harm the welfare of owners and agents alike. Information asymmetries and incentives therefore combine and pose a moral hazard to principals, which owners can reduce by monitoring agents conduct, gaining access to their firms' internal information, and providing incentives that encourage agents to act in the owners' best interests (Schulze et al., 2001). In this sense, the separation between ownership and control has as a main challenge to avoid possible opportunistic behavior of managers that tends to reduce the firm value. In this respect, the literature on corporate governance emphasizes the mechanisms available to protect investors' rights (Shleifer and Vishny, 1997).

A usual classification scheme makes a difference between external and internal control mechanisms. Whereas the market for corporate control is widely known as being the most outstanding external mechanism (Jensen, 1986), there is a number of possible internal mechanisms such as ownership structure and board that have been proved to discipline managers (Jensen, 1993).

\section{Ownership structure: family firms}

The widely dispersed ownership among small shareholders of the modern firm was first approached by Berle and Means (1932). According to them, equity ownership is separated from the day-to-day operation of the corporation, resulting in a conflict of interest between shareholders and managers. However, the fundamental agency problem for listed companies in emerging economies is a conflict of interest between controlling and minority shareholders (Shleifer and Vishny, 1997). The study of La Porta et al. (1999) is the first one to examine the issue of ultimate controlling shareholders and finds, in contrast to the argument of Berle and Means (1932), that relatively few firms are widely held in countries with poor shareholder protection. La Porta et al. (1999) document that corporate ownership tends to be more concentrated and agency problems tend to be more severe in countries with weaker investor protection, which can be seen in emerging markets such as Mexico. Babatz (1997), Husted and Serrano (2002), and Castañeda (2000) extend on La Porta et al. (1999) to investigate the issue of ultimate controlling shareholders in Mexico, because managers of Mexican corporations are usually related to the family of the controlling shareholder. They document that Mexican companies present a higher ownership concentration and many firms are directly or indirectly controlled by one of the numerous industrial conglomerates. A conglomerate is a group of firms linked to each other through ownership relations and controlled by a local family or a small group of investors. Usually, conglomerates are controlled by the dominant shareholders through relatively complex structures including the use of pyramids, cross-holdings and dual class shares ${ }^{[1]}$. We extend this strand of research to examine deeply the

1 Usually, class A shares convey a full voting rights and are tightly held by the controlling family. Most traded stocks have limits regarding voting rights and are held by the minority shareholders (Castañeda, 2000). 
corporate governance role of controlling shareholders in Mexico by investigating the positive (convergence of interest) or negative (entrenchment) effects of controlling shareholders (families) on the relation between the investment opportunity set and the firm value.

The convergence of interest hypothesis refers to the argument that controlling shareholders exert greater monitoring on management, reduce agency conflicts, and maximize firm value (e.g., Demsetz and Lehn, 1985; Shleifer and Vishny, 1997). Accordingly, family firms can provide several benefits. Jensen and Meckling (1976) show that the control of the property can be advantageous as family firms will take long-term profitable projects because they want the company to persist in time and to be inherited by family members. James (1999) argues that families have a longer investment horizon and achieve greater efficiency, while Stein $(1988,1989)$ finds that firms with longer investment horizons are less myopic, maximizing long-term profits. Demsetz and Lehn (1985) show that family firms with high ownership concentration have a lower cost of supervision due to lower agency costs, achieve greater efficiency and maximize the value of the company. In addition, authors such as Jensen (1986) and Stiglitz (1985) argue that by means of a high ownership concentration firms are able to discipline managers and prevent inefficient use of free cash flow.

In contrast, the combination of ownership and control in a family can generate an excessive role by the owner through its leadership, which can lead to problems of management entrenchment. For example, the use of pyramidal groups and crossholdings makes it easier for controlling shareholders to separate ownership and control, and makes difficult for minority shareholders to detect actions that benefit the controlling shareholders (Fama and Jensen, 1983, Shleifer and Vishny, 1997). Private ownership, and particularly the family business, increases the problem because property rights and formal authority are combined with family status and resistance to new changes in the company, which increases the risk of entrenchment of managers. Moreover, an excessive concentrated ownership (in families) can produce adverse consequences since it can become an obstacle when the firm faces profitable growth opportunities demanding a specialized ownership and control (Burkart et al., 1997). Hence, ownership concentration may originate two possible effects: on the one hand, it reduces agency problems by enhancing a more in-depth control and, on the other hand, it could prevent exploiting growth opportunities (De Andres et al., 2005; Gopalan and Jayaraman, 2011). Thus, the core issue is to predict a relation between family ownership and performance when the firm has or does not have growth opportunities.

\section{Board of directors, leverage and growth opportunities}

It is common for firms outside the U.S. to be controlled by insiders, typically a family, financial institution, or the government (La Porta et al., 1998). These insiders usually have concentrated ownership stakes and enjoy control rights far in excess of their cash flow rights. Such disproportionate control, in conjunction with lack of 
intervention from outside shareholders or a market for corporate control, affords insiders significant autonomy over firm decisions even though their ownership stakes are small. In many instances, firm's managers are also associated with the controlling entity. This provides insiders added opportunities to expropriate outside shareholders through the firm's operating and financing decisions (Lins, 2003; Leuz et al., 2009). Prior research provides evidence on how governance mechanisms are designed to motivate managers to make choices leading to the creation of value in the company. In this sense, there exists a large literature that shows a correlation between internal mechanisms of government and performance (Jensen and Murphy, 1990; Morck et al., 1988; Yermack, 1996; Gompers et al., 2003; Castrillo and San Martín, 2007). These mechanisms proposed in the literature include design elements which are held by the companies themselves, such as board of directors and debt.

The board of directors is considered an intermediate entity between owners and managers whose members are elected by the first to monitor and limit the decision freedom of the second. There are a number of empirical studies that explore the relationship of various aspects of the director board with the firm value. The central part of this paper is to analyze the effectiveness of the board as a supervisor of the process of maximizing firm value. Most of the empirical evidence shows a negative relationship between board size and performance. In this sense, authors such as Eisenberg et al., (1998); Jensen (1993); Yermack (1996); Fernández et al. (1998); Azofra et al. (2005); Mak and Kusnadi (2005), and San Martín (2010) find that smaller boards are positively related to a high value of the company.

Board's composition plays an important role. The advantages brought by external directors in widely held firms are clear (Schulze et al., 2001), as they are better able to monitor firm performance, oversee discipline, or even dismiss managers when they are not beholden to the firm (Finkelstein and D'Aveni 1994; Lin 1996; Walsh and Seward, 1990). They also bring needed expertise and perspective to boards which might otherwise lack these skills (Finkelstein and Hambrick, 1996). Despite the advantages of outside directors, family firms are less likely to use them. First, outsiders almost never attain the status of large-block ownership that they sometimes do in widely held firms, and they are likely to be less motivated than family directors (Alderfer, 1988). Second, while their "impartial" status can enhance their ability to offer advice on some decisions, they have little influence on decisions involving family members or other family matters (Nelsen and Frishkoff, 1991). Therefore, outside directors can be limited in their advising role (for example, exploit efficiently the projects when the firm faces profitable growth opportunities), mainly by high levels of ownership concentration in family firms (Rubenson and Gupta, 1996). Consequently, we anticipate important effects associated with family businesses and the composition of their boards of directors.

Finally, the last theme highlighted is financial leverage and the role that debt structure plays both in the presence and in the absence of profitable projects. In presence of growth opportunities the underinvestment problem is likely to arise 
(Myers, 1977). It is widely known that the underinvestment problem stresses the shortcoming of excessive debt financing in the presence of growth opportunities since too much debt can prevent managers from undertaking positive NPV projects. If this is the case, under the pressure of high financial leverage ratios managers acting on behalf of the shareholders may forgo some profitable projects. Following De Andres et al. (2005), the rationality underlying this fact is the priority that debtors have over firm cash flows in comparison to shareholders. If debt holders are the first claimholders, managers do not find it worthwhile undertaking investment projects whose cash flows will not be perceived by company owners but by creditors. As Myers (1977) and McConnell and Servaes (1995) argue, the higher the growth opportunities are set, the lower the leverage rate should be, therefore we expect a negative relationship between debt and firm value in presence of growth opportunities.

On the other hand, the managers prefer self-financing rather than undertaking new issues of equity or debt, they do not want to be reviewed by the capital markets or increase the likelihood of insolvency in the company, while shareholders prefer not to retain cash flow and distribute it as dividends. Therefore the distribution of free cash flow can generate confrontations between managers and owners and lead to an overinvestment problem emphasized by Jensen's theory of free cash flow (1986). Jensen (1986) stated that if free cash flow in a company is not used or invested to maximize or to balance the best interest of shareholders, then it raises agency problems. The manager may choose to invest in an unprofitable project due to his or her self interest. As a result, the company may be in the position of low growth. This overinvestment view emphasizes the negative consequences of too much cash flow under the discretionary control of managers. Thus, a way to safeguard the value of the firm is to issue debt, so that managers lose control over free cash flow (Grossman and Hart, 1982; Jensen, 1986; Harris and Raviv, 1991; De Andres et al., 2005; Castrillo et al., 2010; San-Martin and Duran-Encalada, 2012). This overinvestment view applies when the firm has no growth opportunities, and is closely related to the free cash flow situation (Jensen, 1986 and 1993; Lang et al., 1996; Smith and Watts, 1992; McConnell and Servaes, 1995; Singh and Faircloth, 2005). According to this view, a positive relation exists between debt and performance when the firm has no growth opportunities since the higher the leverage the more in-depth is the control undertaken by lenders (Lima and López, 2010).

\section{Mexican context and institutional framework}

The framework has been broadened with the "Law and Finance approach" (La Porta et al., 1997, 1998, 1999, and 2000). Following these authors, it is logical enough to suppose that the system of corporate governance of a particular country and the predominance of certain supervisory mechanisms over others, whether of an internal or external nature, would be strongly influenced by the institutional framework of the country. This is a view confirmed by works such as Roe (2000), Francis et al. (2001), Denis and McConnell, (2003), within the line of research initiated by Rajan and Zingales 
(1995) and La Porta et al. (1997, 1998, 2000, 2002), which highlights the differences between the international economic environments as well as the relevance of the institutional framework on the decision making process within the firm. The conflict between managers and shareholders differs from one country to another and might not prove worthwhile to use the same tools to solve it. As it has been shown (Becht and Röell, 1999; Bianco and Casavola, 1999; La Porta et al., 1997, 1998, 2000, 2002; Roe, 2000; Francis et al., 2001; Denis and McConnell, 2003; and San Martín, 2010), the relationship between large controlling shareholders and weak minority shareholders is an important issue in these countries. Mexico belongs to the French tradition of the civil-law countries. In these nations shareholders' rights are not sufficiently protected, and the concentration of the ownership in the hands of large block-holders (mainly families) arises to shield shareholders' interests (Khanna and Palepu, 1999; La Porta et al., 1999; Barca and Becht, 2001; Facio and Lang 2002).

Thus, the institutional environment in which the corporation operates can affect its investment opportunity set (Smith and Watts, 1992), and consequently can have an impact on the relation between firms' investment opportunities and performance, the issue examined in this paper. We believe that the institutional environment in Mexico provides an ideal setting for examining the corporate governance role of controlling shareholders between the investment opportunities set and firm value for the following reasons. La Porta et al., $(1998,1999,2000)$ document that corporate ownership tends to be more concentrated and agency problems tend to be more severe in countries with a weaker investor protection, as can be seen in emerging markets such as Mexico.

In Mexico families play an essential role in defining the corporate governance practices. Analytically, the predominance of family corporate structure has been explained in terms of conflict theory, assuming a framework to protect inefficient property rights (Castillo-Ponce, 2007). In this context, the choice of maintaining the company in the hands of the family is a rational decision; this choice represents the strategy to increase family's share value.

The most dominant companies in Mexico, regardless of size, are owned and managed by one or more families, usually descendants of the founding family. This creates some difficulties for gaining access to information on ownership and control structures of the companies $^{[2]}$. Despite these difficulties, it is clear that two main features characterize the ownership and control structures of most companies in Mexico. First, these companies present a much higher ownership concentration, and second, many firms are directly or indirectly controlled by one of the numerous financial and/or industrial conglomerates. A conglomerate is a group of firms linked to each other through ownership relations and controlled by a local family, or a small group of investors. Usually, conglomerates are

2 Accessibility was drastically improved in 2002 when the annual reports of listed companies, which are submitted to the National Banking and Securities Commission (in Spanish Comisión Nacional Bancaria y de Valores, CNBV) of Federal Government, begin to be placed on the web page of the Mexican Stock Exchange (in Spanish, Bolsa Mexicana de Valores, BMV). 
controlled by the dominant shareholders through relatively complex structures, including the use of pyramids, cross-holdings and dual class shares ${ }^{[3]}$.

High ownership concentration and conglomerate structures also have an important effect on the board room composition. Most board members in Mexican companies are related to controlling shareholders through family ties, friendship, business relationships, and labor contracts. Babatz, (1997), and Husted and Serrano, (2002) show that 53 percent of directors or executive seniors are also directors of other companies of the same group, or are relatives to companies' executives. According to Castañeda (2000), in most Mexican firms the president of the board is usually the main stockholder and the CEO, and therefore he or she practically does not have opposition from independents board members. On average, only 20 percent of the firms present a majority of external members on the board and this fact does not necessarily mean independence, since they could be related to another company of the same business group ${ }^{[4]}$. Our data follows this pattern, as we can see in panel A and B of Table 1 , only 40.54 percent of the companies show a majority of independent directors. In addition, in 40 percent of the companies the CEO is also the chairman of the board. As we can see, the companies' board composition in Mexico is very peculiar because this country has a high ownership concentration. In Mexico, a company is usually defined as a family firm when the founder or family member holds more than 40 percent of the company's property, unlike other countries' studies criteria, where to classify as a family company depends on whether the founder holds more than 20 or 30 percent of the property or the CEO is a member of the firm.

Table 1. Descriptive Data for Board and CEO of the 83 Listed Firms Sample

\begin{tabular}{|c|c|c|c|c|}
\hline \multicolumn{3}{|c|}{$\begin{array}{l}\text { Panel A: Percentage of companies whose CEO } \\
\text { is chairman or not of the board. }\end{array}$} & \multicolumn{2}{|c|}{$\begin{array}{l}\text { Panel B: Classified by number of directors: } \\
\text { Shareholder, Independent and Related. }\end{array}$} \\
\hline 2005 to 2009 & Percentage & Total & 2005 to 2009 & Percentage \\
\hline CEO- Chairman & 40 & 36 & SHR & 46.32 \\
\hline \multirow[t]{2}{*}{$\begin{array}{l}\text { CEO-Non } \\
\text { Chairman }\end{array}$} & 60 & 54 & IND & 40.54 \\
\hline & & & REL & 12.95 \\
\hline TOTAL & 100 & 90 & $\begin{array}{l}\text { Members of the } \\
\text { family on the board }\end{array}$ & 23.29 \\
\hline
\end{tabular}

Panel A presents the breakdown of those companies where the CEO holds or not the role of the chairman. Panel B presents data for the boards' breakdown classified by Shareholder, Independent and Related ${ }^{[5]}$.

Source: Mexican Stock Exchange classification, 2005-2019 annual reports.

3 Usually, class A shares convey a full voting rights and are tightly held by the controlling family. Most traded stocks have limits regarding voting rights and are held by the minority shareholders (Castañeda, 2000).

4 Besides, on average, $35.2 \%$ belong to the president family and around $57 \%$ of board members are employees or relatives of the president.

5 The shareholder director is the one chosen based on their character as significant shareholder. Independent directors are persons who are not linked with the management team of the company and meet the requirements of the code of best corporate practices. Related director is one who is not in any of the cases listed in the definitions of independent or shareholder. 


\section{Methodology}

\section{The sample and data collection}

The sample includes the total number of the companies listed in the Mexican Stock Exchange for the period 2005-2011. Out of 132 listed companies, non-profit companies, companies that do not include enough information in their financial statements, as well as financial institutions, were excluded. The latter are not comparable to other industries and there are some difficulties in calculating Tobin's $Q$ for banks. We were thus left with 83 companies. We obtained the annual reports and financial indicators from Economatica, and Isi Emerging Markets. Information about industrial sector was obtained from company annual reports published by the Mexican Stock Exchange on its website. Table 2 shows the companies that make our sample, according the sectors to which they belong.

Table 2. Number and Percentage of Family and Non-Family Firms by Sector

\begin{tabular}{lcc}
\hline \multicolumn{1}{c}{ Sector } & Number & Percentage \\
\hline Materials & 16 & 19.3 \\
Industrial & 22 & 26.5 \\
Services and non-basic consumer goods & 16 & 19.3 \\
Common consumer products & 18 & 21.7 \\
Health & 4 & 4.8 \\
Telecommunications services & 7 & 8.4 \\
Total & 83 & 100.0 \\
\hline
\end{tabular}

Source: Mexican Stock Exchange classification code, 2011.

Certainly, the companies in the sample are basically medium to large companies compared with the average Mexican firm size either in terms of assets, sales or employees. This could raise some caveats about a possible sample bias, however, descriptive statistics in Panel A of Table 3 shows that firm size (in terms of assets) is quite heterogeneous and highly dispersed around the mean value, so it can be assumed that the results are not biased by size issues. The sample composition is quite industry-balanced, although there is a slight bias towards industries and consumer products firms at the expense of health or telecommunications companies that can be explained by the heavier concentration of the former in the Mexican market.

A key aspect of our study is the identification of the availability of growth opportunities, where the choice of how to measure this becomes crucial issue. The price-earnings ratio ${ }^{[6]}$ (PER) has been chosen. This is obtained by dividing equity market value by net income. There is a general agreement that this variable is a good indicator of future growth opportunities by incorporating the market point of view on the firm ability to generate cash flows in the future (Smith

6 Some authors use other variables as the market equity value to total asset ratio (Lasfer, 1995), the market asset value to cash flow ratio (Smith and Watts, 1992) or sales rate of growth (McConnell and Servaes, 1995; La Porta et al., 2000). This last variable will be used later as a sorting variable in order to test the robustness of the results. 
and Watts, 1992; Lang and Stuz, 1994; Berger and Ofek, 1995). PER is positively related to growth opportunities, so that, the higher the PER the higher the impact of growth opportunities on firm value (Chung and Charoenwong, 1991). As a consequence, the sample was split into two sub-samples (firms with or without profitable growth opportunities) according to McConnell and Servaes (1995). The sample was first divided into three groups as a function of the PER value. Those companies in the upper third are certain to have more growth opportunities, while those in the lower third could be quite reasonably characterized by the lack of valuable projects. This work uses another one additional measure of growth opportunities, the sales rate of growth (McConnell and Servaes, 1995; La Porta et al., 2000), as explained later.

Performance is measured using Tobin's $Q$ ratios $(\mathrm{Q})$ or the asset market-tobook ratio. The remaining of corporate governance variables are debt (DEBT), family ownership percentage (FAMOWN) ${ }^{[7]}$, ownership concentration measured also by the ownership of the three largest shareholders (OWN3), and the size (BSIZE) and composition of the board as represented by the percentage of independent (IND) and shareholders (SHA) directors. In addition to the aforementioned variables, we include some control variables in order to embody some additional determinants of the performance. Based on what has been done in previous works, (De Andres et al., 2005; Delgado, 2003; Wang, 2006; Warfield et al., 1995; De Andres et al., 2004), we have included the firm size measured by assets that, to some extent, proxies the problems stemming from asymmetric information (Devereux and Schiantarelli, 1990). Descriptive statistics for the sample and for the sub-samples are shown in Panel A and B of Table 3.

Table 3. Sample Descriptive Data

\begin{tabular}{|c|c|c|c|c|}
\hline \multicolumn{5}{|c|}{ Panel A: Total Sample } \\
\hline Variables & Mean & Std. Dev. & Min & Max \\
\hline Q & 1.47 & 1.04 & 0.25 & 6.97 \\
\hline DEBT & 0.43 & 0.20 & 0.01 & 1.23 \\
\hline FAMOWN & 55.29 & 22.06 & 0 & 1 \\
\hline OWN3 & 64.56 & 24.11 & 0.02 & 1 \\
\hline BSIZE & 11.59 & 3.66 & 5 & 20 \\
\hline IND & 4.16 & 2.39 & 0 & 11 \\
\hline SHA & 5.21 & 2.40 & 3 & 14 \\
\hline Assets & 41028 & 90674 & 153 & 945616 \\
\hline
\end{tabular}

7 The most dominant companies in Mexico (regardless of size) are owned and managed by one or more families or descendants of the founding family (San Martín and Duran-Encalada, 2012). 


\begin{tabular}{|c|c|c|c|c|c|c|c|c|}
\hline \multicolumn{9}{|c|}{ Panel B: Sub-samples divided by Growth Opportunities } \\
\hline \multicolumn{5}{|c|}{ PER } & \multicolumn{4}{|c|}{ PER } \\
\hline \multicolumn{5}{|c|}{ Low Growth } & \multicolumn{4}{|c|}{ High Growth } \\
\hline Variables & Mean & $\begin{array}{l}\text { Std. } \\
\text { Dev. }\end{array}$ & Min & Max & Mean & Std. Dev. & Min & Max \\
\hline Q & 1.24 & 0.701 & 0.379 & 4.803 & 1.44 & 0.64 & 0.25 & 3.15 \\
\hline DEBT & 0.508 & 0.223 & 0.109 & 1.233 & 0.403 & 0.199 & 0.015 & 0.842 \\
\hline FAMOWN & 0.575 & 0.206 & 0.095 & 0.978 & 0.576 & 0.223 & 0.000 & 0.910 \\
\hline OWN3 & 64.81 & 26.30 & 0.05 & 1 & 67.46 & 22.32 & 0.116 & 1 \\
\hline BSIZE & 11.760 & 3.705 & 5 & 20 & 11.37 & 3.959 & 5 & 20 \\
\hline IND & 4.5 & 2.008 & 0 & 9 & 5.959 & 2.910 & 1 & 11 \\
\hline SHA & 7.076 & 1.958 & 2 & 12 & 5.013 & 2.679 & 0 & 10 \\
\hline Assets & 31280 & 47428 & 237 & 264030 & 33769 & 50554 & 153 & 274704 \\
\hline
\end{tabular}

Source: Mexican Stock Exchange for the period 2005-2011.

As stated before, the sample contains data of 83 firms with seven year observations in each originating in a panel data with 581 observations. Given the aim of the study, the panel data methodology seems to be the most accurate (Arellano and Bover, 1990; Arellano, 1993). The fixed-effects term is unobservable, and hence becomes part of the random component in the estimated model. It is quite convincing that each one of the firms in the sample has its own specificity (e.g., the way it is run by the managers, the impression it makes to the market, the way it generates growth opportunities, etc.). This specificity is different from a company to company and it is almost certain to be kept throughout the study period. A pooling analysis of all the companies without noticing these peculiar characteristics could cause an omission bias and distort the results. The random error term it controls both, the error in the measurement of the variables and the omission of some relevant explanatory variables. With regard to the basic model to be estimated, a multivariate regression model was built including the previously cited variables. We use Tobin's $Q(Q)$ as the performance measure and regress it on two models, according to the alternative ways to measure property concentration: FAMOWN and OWN3. In the models we use the natural logarithms of board size and firm size, LBSIZE and LTA, respectively. These are shown as follows:

$\mathrm{Q}=\beta+\beta_{1} \mathrm{DEBT}_{i t}+\beta_{2}$ FAMOWN $_{\text {it }}+\beta_{3} \mathrm{LBSIZE}_{i t}+\beta_{4} \mathrm{IND}_{\text {it }}+\beta_{5} \mathrm{SHA}_{i t}+\beta_{6} \mathrm{LTA}_{i t}+\varepsilon_{\text {it }}$ $Q=\beta+\beta_{1}$ DEBT $_{i t}+\beta_{2}$ OWN3 $_{i t}+\beta_{3}$ LBSIZE $_{i t}+\beta_{4}$ IND $_{i t}+\beta_{5}$ SHA $_{i t}+\beta_{6}$ LTA $_{i t}+\varepsilon_{i t}$

Model 1 Model 2

Where $i$ refers to the firms and $t$ to the year $(i=1 \ldots .83 ; \mathrm{t}=1 \ldots .7)$.

\section{Discussion}

\section{Regression Analysis}

The results of the panel data estimation are displayed in Table 4. Model one measures family ownership by using FAMOWN while model two considers as an alternative 
measure OWN3. The Hausman test reveals the importance of the fixed effect component, so that within groups estimation method becomes necessary in order to deal with the constant unobservable heterogeneity.

Table 4. Results of estimations based on PER

Model 1

\begin{tabular}{|c|c|c|c|c|c|c|}
\hline \multicolumn{4}{|c|}{$\begin{array}{l}\text { Panel A: Presence of Growth Opportunities with } \\
\text { PER }\end{array}$} & \multicolumn{3}{|c|}{$\begin{array}{c}\text { Panel B: Absence of Growth Opportunities } \\
\text { with PER }\end{array}$} \\
\hline add & Coefficient & t-statistic & P-value & Coefficient & t-statistic & P-value \\
\hline DEBT & -0.4799606 & -2.05 & {$[0.042]$} & 0.675333 & 2.33 & {$[0.021]$} \\
\hline FAMOWN & -0.4705819 & -1.20 & [0.232] & 0.7986329 & 2.14 & [0.039] \\
\hline LBSIZE & -2.601172 & -2.50 & [0.013] & -0.532537 & -1.70 & [0.092] \\
\hline IND & 0.4760229 & 2.24 & {$[0.026]$} & 0.306753 & 0.71 & [0.476] \\
\hline SHA & -0.3669473 & -3.20 & [0.002] & 0.032822 & 1.77 & [0.079] \\
\hline LAT & 0.1281382 & 0.87 & [0.383] & -0.09893 & -0.93 & [0.351] \\
\hline _cons & 0.9236327 & 0.58 & [0.396] & 0.317440 & 2.73 & [0.007] \\
\hline R-squared & 0.21 & & & 0.17 & & \\
\hline $\begin{array}{l}\text { Hausman } \\
\text { Test }\end{array}$ & 47.03 & & {$[0.000]$} & 25.72 & & {$[0.000]$} \\
\hline
\end{tabular}

Model 2

\begin{tabular}{|c|c|c|c|c|c|c|}
\hline \multicolumn{4}{|c|}{$\begin{array}{l}\text { Panel A: Presence of Growth Opportunities with } \\
\text { PER }\end{array}$} & \multicolumn{3}{|c|}{$\begin{array}{c}\text { Panel B: Absence of Growth Opportunities } \\
\text { with PER }\end{array}$} \\
\hline add & Coefficient & t-statistic & P-value & Coefficient & t-statistic & P-value \\
\hline DEBT & -0.4518110 & -1.92 & {$[0.057]$} & 0.7157122 & 2.46 & {$[0.015]$} \\
\hline OWN3 & -0.2745623 & -1.58 & [0.115] & 0.3194998 & 2.71 & [0.007] \\
\hline LBSIZE & -2.5966410 & -2.49 & [0.014] & -0.5837899 & -1.74 & [0.084] \\
\hline IND & 0.4529111 & 2.10 & {$[0.037]$} & 0.2152203 & 0.50 & [0.617] \\
\hline SHA & -0.3598032 & -3.12 & {$[0.002]$} & 0.0429041 & 1.23 & [0.220] \\
\hline LAT & 0.1402697 & 0.94 & [0.351] & -0.1740820 & -1.09 & [0.279] \\
\hline _cons & 0.9548920 & 0.99 & {$[0.324]$} & 0.4860170 & 2.71 & [0.008] \\
\hline R-squared & 0.19 & & & 0.17 & & \\
\hline $\begin{array}{l}\text { Hausman } \\
\text { Test }\end{array}$ & 46.21 & & {$[0.000]$} & 29.78 & & [0.001] \\
\hline
\end{tabular}

These results confirm the hypothesis about the influence of leverage, board of directors, and ownership structure on value creation. First, the financial leverage ratios are significant in all the estimations, although its role is quite different depending on the existence or the absence of growth opportunities. When firms do not have profitable projects (Panel B, Table 4), the DEBT positive sign suggests the debt contribution to increase the company value by disciplining managers, reducing the free cash flow problem (Jensen, 1986). On the other hand, DEBT coefficient becomes negative in firms with high growth opportunities (Panel A, Table 4), emphasizing the negative impact that debt can have on performance when firms face growth opportunities. These findings suggest, first, that the free cash flow problems in absence of growth opportunities are controlled, in part, by the degree of obligation 
to comply with the clauses that debt contracts impose on manager discretion and, second, the importance of the problems of underinvestment that debt can generate in firms with more investment opportunities and greater access to positive net present value projects (Gaver and Gaver, 1993; Smith and Watts, 1992; De Andres et al., 2004; De Andres et al., 2005). Our result could be understood as the important role that debt plays over performance that is different when the firm has or does not have growth opportunities.

Concerning the family ownership structure variable, this has a different impact in both sub-samples, although it only comes out significant when firms do not have growth opportunities. The family ownership has a positive influence on performance in firms without growth opportunities and negative relationship with Tobin's $Q$ in the presence of growth opportunities. This result is consistent with the previous literature and demonstrates again the existence of some agency problems inside the companies and suggests a combination of alignment and entrenchment effects (Morck et al., 1988). In the face of absence growth opportunities, a majority control in families seems to increase the performance. However, when we consider only firms with growth opportunities the relationship becomes negative, indicating a decrease in the firm value in family firms, even though there this relationship is not statistically significant. The explanation that might be attributed to this dissimilar behaviour of ownership structure in different institutional frameworks might be related to agency problems and information asymmetries that differ in accordance with the firm's institutional environment. As we have seen in the case of Mexico, ownership structure is highly concentrated in families and this plays a fundamental role as control mechanism.

In the absence of growth opportunities, the ownership and control structure (FAMOWN) play an important role in reducing the agency problems. In this case, ownership concentration becomes necessary because in absence of investment opportunities, the family ownership acts as a disciplining mechanism of behavior management. This result shows that in Mexican firms, an increase in ownership concentration is a factor associated with better performance. This argument goes along with the traditional assumption that ownership concentration in families provide closer supervision on the manager, based on the idea that when managers are faced with low investment opportunities they might be tempted to act opportunistically. In this case high levels of ownership can compensate the reduced levels of investor protection that exist in the Mexican institutional framework. However, when we talk about firms with growth opportunities, the combination of ownership and control seems to be disadvantageous, because this combination can generate an excessive role by the owner through its leadership, deteriorating shareholders' wealth. Furthermore, the existence of family control on the ownership structure of companies with growth opportunities could lead, to some extent, to wasting these opportunities (Carlin and Mayer, 1998; De Andres et al., 2005). The results in model two, using OWN3, are similar to those in model one. 
Another variable, the board size (LBSIZE), presents a negative relationship with the performance when the firm has or does not have significant cash flows (presence or absence of growth opportunities). It was observed that small boards of directors, in absence or presence of growth opportunities, contribute in a significant way to increase the performance. This leads us to conclude that the possible benefits of greater supervision over the management by numerous board members are outweighed by the problems of coordination and information that can arise in the decision-making process (Jensen, 1993; Yermarck, 1996; Azofra and López 2005, San Martín, 2010). When we focus on independent board members (IND), our results show a positive relation between independent members and performance (with or without growth opportunities), but the variable is significant only in the sub-sample of firms with growth opportunities. Its positive correlation with firm value represents the convergence of independent directors and shareholders' interest. The independent corporate boards are associated with better performance for firms with growth opportunities, because the presence of independent directors on the board allows the firm to exploit projects with positive net present value (growth opportunities), given their professional background and experience.

However, the shareholders board members (SHA) show a positive and significant relationship with performance only for firms without growth opportunities, indicating that high number of shareholders in the board improve the firm performance by high supervision on managers. Nevertheless, the sign of the variable depends on the growth opportunities availability. The results confirm this dual behavior, when companies have growth opportunities shareholders are significant and negatively related to firm value. Nevertheless, when the firms have growth opportunities, a larger number of shareholder directors on the board could hinder the decision making process, especially because in the Mexican market the majority of such directors are part of a controlling family, and usually they have close relationships with the managers, and they do not represent any opposition to managers' decisions. This lack of professionalism that independent directors might exercise in the decision-making process, could impact negatively on the firm performance when the companies face profitable investment projects. Thus, the influence of shareholders directors is not the same when the firm has or does not have growth opportunities. In firms without profitable projects, the shareholder directors will help in the value creation process, however, when the company faces profitable investment projects their role seems to "relax". This finding could explain the constant ups and downs of business in the Mexican market.

Finally, with respect to the control variable size (LTA), this has a positive coefficient from firms with high-growth opportunities and negative in firms without growth opportunities, but do not have any significant effect in each one of the subsamples.

One of the study's concerns is to know whether the results that have been obtained are contingent upon the specification of the model. In order to assess the robustness of the results to alternative specification and variable measurements a sensitivity analysis is added consisting of an alternative identification of growth 
opportunities. In this case, we decided to measure growth opportunities according to the sales rate of growth -SRGR- (McConnell and Servaes, 1995; La Porta et al., 2000; De Andres et al., 2005). Again, we divided the whole sample into three and then two sub-samples considering their growth opportunities, and regress Tobin's $Q(Q)$ on the variables, considering the alternative measures of ownership concentration (FAMOWN and OWN3). Results are shown in Table 5.

Table 5. Results of estimations based on SRGR

Model 1

\begin{tabular}{|c|c|c|c|c|c|c|}
\hline \multicolumn{4}{|c|}{$\begin{array}{l}\text { Panel A: Presence of Growth Opportunities with } \\
\text { SRGR }\end{array}$} & \multicolumn{3}{|c|}{$\begin{array}{l}\text { Panel B: Absence of Growth } \\
\text { Opportunities with SRGR }\end{array}$} \\
\hline Variables & Coefficient & t-statistic & P-value & Coefficient & t-statistic & P-value \\
\hline DEBT & -0.6942499 & -3.07 & {$[0.003]$} & 0.3520154 & 2.39 & {$[0.018]$} \\
\hline FAMOWN & -0.4963814 & -1.05 & [0.293] & 0.3186631 & 1.74 & [0.084] \\
\hline LBSIZE & -1.736012 & -2.07 & [0.040] & -0.6084392 & -1.69 & [0.094] \\
\hline IND & 0.1447820 & 2.10 & {$[0.038]$} & 0.1545861 & 0.67 & [0.503] \\
\hline SHA & -0.1690060 & -1.91 & [0.057] & 0.1623779 & 0.98 & [0.329] \\
\hline LAT & 0.1847002 & 1.36 & [0.175] & -0.4330879 & -1.09 & [0.277] \\
\hline _cons & 0.726875 & 0.84 & [0.402] & 0.552369 & 0.34 & [0.737] \\
\hline R-squared & 0.26 & & & 0.14 & & \\
\hline $\begin{array}{l}\text { Hausman } \\
\text { Test }\end{array}$ & 62.78 & & {$[0.000]$} & 28.90 & & [0.001] \\
\hline
\end{tabular}

Model 2

\begin{tabular}{|c|c|c|c|c|c|c|}
\hline \multicolumn{4}{|c|}{$\begin{array}{l}\text { Panel A: Presence of Growth Opportunities with } \\
\text { PER }\end{array}$} & \multicolumn{3}{|c|}{$\begin{array}{l}\text { Panel B: Absence of Growth } \\
\text { Opportunities with PER }\end{array}$} \\
\hline Variables & Coefficient & t-statistic & P-value & Coefficient & t-statistic & P-value \\
\hline DEBT & -0.6375161 & -2.89 & [0.004] & 0.3945149 & 2.59 & [0.011] \\
\hline OWN3 & -0.4646074 & -0.31 & [0.753] & 0.4683410 & 2.93 & [0.004] \\
\hline LBSIZE & -1.8230910 & -2.17 & [0.032] & -0.5699796 & -1.80 & [0.074] \\
\hline IND & 0.1579396 & 2.32 & [0.022] & 0.2226424 & 0.95 & [0.344] \\
\hline SHA & -0.1752790 & -1.97 & [0.050] & 0.2171965 & 0.92 & [0.360] \\
\hline LAT & 0.1880925 & 1.38 & [0.168] & -0.4559408 & -1.15 & [0.252] \\
\hline _cons & 0.7794470 & 1.38 & [0.168] & 0.4251042 & 0.09 & [0.928] \\
\hline R-squared & 0.23 & & & 0.14 & & \\
\hline $\begin{array}{l}\text { Hausman } \\
\text { Test }\end{array}$ & 66.35 & & [0.000] & 39.28 & & [0.000] \\
\hline
\end{tabular}

Table 5 reports the results, and these are consistent with the previous ones: debt reduces the performance in firms with growth opportunities but increases the firm value in firms without growth opportunities. Family ownership is negatively associated with the performance, but in low-growth firms a positive relation exists between firm performance and family ownership concentration. In addition, independent corporate boards have a negative coefficient in all model specifications and have a statistical significant relationship with firm performance. Results show that the presence of a larger number of independent members in the board has benefited the company in 
firms with presence of growth opportunities. Results also show that the presence of a large number of shareholders in the board can lead to entrenchment problems given the high ownership concentration.

\section{Conclusions}

Research about the relationship between corporate mechanisms and performance begins with the work of Berle and Means (1932). Traditionally mechanisms as ownership structure, debt and board structure arise as different factors affecting those opportunities' utilization. Essentially, these mechanisms try to give managers the incentive to efficiently use firm cash flows and to impede wasteful uses. Our research differs from prior studies which investigate the relation between corporate governance characteristics and performance by incorporating the role of growth opportunities, a prevailing institutional factor in Mexico, because the extent to which corporate governance controls can provide effective monitoring is likely to be conditioned on a firm's production-investment attributes characterized as the mix of assets-in-place versus growth options (Andersen et al., 1993).

The results show that ownership structure, leverage and board of directors affect the firm value as well as the type of influence depends on the presence or absence of investment opportunities. Family ownership, composition of board and leverage play a dual role: increase the performance when there are no investments projects, but impact negatively in presence of growth opportunities. Family ownership, for example, helps to create value by disciplining managers in those companies without growth opportunities, while it has a negative effect in those firms with investment opportunities due to the propensity to wasting profitable projects. The reason is because the combination of ownership and control can generate an excessive role by the owner through its entrenchment, deteriorating shareholders' wealth.

In short, our results confirm the relationship between ownership structure, board of directors, leverage, growth opportunities and performance. We find a positive relation between family control and performance in firms without growth opportunities and this relation will be moderated by corporate mechanisms when the companies have access to positive NPV projects. In this sense, when we focus on the control aspects of proprietary directors on the boards and debt, we find that they provide effective oversight function but only from firms with absence of growth opportunities.

The results achieved are consistent with those obtained by a number of authors from other countries. Some future research directions can be pointed out. One of these has to do with the interaction of different corporate mechanisms issue, mainly related to the particular institutional country context. These efforts will surely open new avenues in research on corporate governance, since it has been shown that the mechanisms of government are not independent. The authors would also like to consider a broader time analysis, able to reveal how governance mechanisms can affect the earnings management in companies over time. In this way, models with 
a larger database could incorporate temporal effects in the estimation, which would give us a broader view of the results and the causality relationship among some of the most significant variables.

\section{References}

Andersen, D., Francis, J. and Stokes, D. (1993). Auditing, directorships and the demand for monitoring. Journal of Accounting and Public Policy, 12 (4), 353-375.

Andres, P., Azofra, V. and Rodríguez, J. A. (2000). Endeudamiento, oportunidades de crecimiento y estructura contractual: Un contraste empírico para el caso español. Investigaciones Económicas, 24(3), 641-79.

Anderson, R. and Reeb, D. (2003). Founding family ownership and firm performance: Evidence from the S\&P 500. Journal of Finance, 58(3), 1301-1328.

Arellano, M. and Bover, O. (1990). La econometría de datos de panel. Investigaciones Económicas (Segunda época), 14(1), 3-45.

Arellano, M. (1993). Introducción al análisis econométrico con datos de panel, La industria y el comportamiento de las empresas españolas. Ensayos en homenaje a Gonzalo Mato. Alianza Editorial, Madrid, 23-47.

Azofra, V., Andrés de, P. y López, F. (2005). Corporate Boards in OECD Countries: Size, Composition, Functioning and Effectiveness. Corporate Governance: An International Review, 13(2), 197-210.

Barca, F., and Becht, M. (2001). The Control of Corporate Europe. Oxford University Press.

Babatz, G. (1997). Agency Problems, Ownership Structure, and Voting Structure under Lax Corporate Governance Rules: The Case of Mexico. Ph.D. thesis; Harvard University.

Becht, B. and Röell, A. (1999). Corporate governance in Europe, blockholdings in Europe: an international comparison. European Economic Review, 43, 1049-56.

Becht, M., Bolton, P. and Roell, A. (2002). Corporate governance and control. National Bureau of Economic Research [NBER], Working Paper No. 9371.

Available at http://papers.ssrn.com/so13/papers.cfm?abstract_id=343461

Bianco M. and Casavola P. (1999). Italian Corporate Governance: Effects on Financial Structure and Firm Performance. European Economics Review, 43, 1057-69.

Berger, P.G. and Ofek, E. (1995). Diversification's effect on the firm value. Journal of Financial Economics, 37, 39-65.

Berle, A. and Means, G. (1932). The Modern Corporation and Private Property. Commerce Clearing House, New York, NY.

Bukit, R.B. and Iskandar, T.M. (2009). Surplus Free Cash Flow, Earnings Management and Audit Committee. Int. Journal of Economics and Management, 3(1), 204-223.

Bushman, R.M. and Smith, A.J. (2001). Financial accounting information and corporate governance. Journal of Accounting and Economics, 32, 237-333.

Castañeda, G. (2000). Governance of large corporations in Mexico and productivity implications. ABANTE. Studies in Business Management, 3(1), 57-89. 
Castillo-Ponce, R. (2007). Entre familia y amigos: La elección de la estructura de propiedad corporativa. Estudios Económicos, 22, 3-18.

Castrillo, L.A. and San Martín-Reyna, J.M. (2007). La propiedad familiar como mecanismo disciplinador de la dirección en las empresas mexicanas: Una evidencia empírica. Contaduría y Administración, 222, 59-82.

Castrillo, L.A.; Marcos, S. and San Martín-Reyna, J.M. (2010). Corporate governance, legal investor protection, and performance in Spain and the United Kingdom. Corporate Ownership and Control Journal, 7(3), 416-429.

Chen, K.Y. and Liu, J.L. (2010). Earnings management, CEO domination, and growth opportunities -Evidence from Taiwan. International Journal of Public Information Systems, 1, 43-69.

Chen, K.Y., Elder R.J. and Hung, S. (2010). The investment opportunity set and earnings management: Evidence from the role of controlling shareholders. Corporate Governance: An International Review, 18(3), 193-211.

Chung, K. and Charoenwong, C. (1991). Investment options, assets in place, and the risk of stocks. Financial Management, 20, 21-33.

Chung, R., Firth, M. and Kim, J.B. (2005). Earnings Management, Surplus Free Cash Flow, and External Monitoring. Journal of Business Research, 58, 766-776.

Claessens, S., Djankov, S. and Lang, L. (2000). The separation of ownership and control in East Asian corporations. Journal of Financial Economics, 58, 81-112.

Claessens, S., Djankov, S., Fan, J. and Lang, L. (2002). Disentangling the incentive and entrenchment effects of large shareholders. Journal of Finance, 57, 2741-2771.

De Andres, P.A., López, F.J. and Juan Rodríguez, A. (2005). Financial decisions and growth opportunities: a Spanish firm's panel data analysis. Applied Financial Economics, 15, 391-407.

De Andrés, P.A., San Martín, P.M., y Saona, P.H. (2004). Decisiones Financieras en la Empresa Chilena: Una Mirada a través de las Oportunidades de Crecimiento. Revista Abante, 7(1), 3-34.

Delgado, M.M. (2003). Factores determinantes de la discrecionalidad contable: Una aplicación empírica a las empresas cotizadas españolas. Servicio de Publicaciones de la Universidad de Burgos, Burgos.

Demsetz, H. and Lehn, K. (1985). The structure of corporate ownership: Causes and consequences. Journal of Political Economics, 93, 1155-1177.

Denis, D.K. and McConnell, J.J. (2003). International corporate governance. Journal of Financial and Quantitative Analysis, 38(1), 1-36.

Devereux, M. and Schiantarelli, F. (1990). Investment, financial factors, and cash flow: Evidence from UK panel data. In R.G. Hubbard [ed], Asymmetric information, corporate finance and investment, University of Chicago Press, 279-306.

Doyle, J., Ge, W. and McVay, S. (2007). Accrual quality and internal control over financial reporting. The Accounting Review, 44, 193-223.

Eisenberg, T., Sundgren, S. and Wells, M.T. (1998). Larger board size and decreasing firm value in small firms. Journal of Financial Economic, 48, 35-54. 
Faccio, M., and Lang, L. (2002). The ultimate ownership of Western European corporations. Journal of Financial Economics, 65, 365-395.

Fama, E.F. (1980). Agency problems and the theory of the firm. Journal of Political Economy, 88, 288-307.

Fama, E.F. and Jensen, M.C. (1983). Separation of ownership and control. Journal of Law and Economics, 26, 301-325.

Fernández, A., Gómez-Ansón, S. and Fernández, C. (1998). El papel supervisor del consejo de administración sobre la actuación gerencial: Evidencia para el caso español. Investigaciones Económicas, 22, 501-516.

Francis, J., I. Khurana and Pereira, R. (2001). Investor protection Laws, Accounting and Auditing Around the World. Working Paper (SSRN). Available at http://papers.ssrn. com/sol3/papers.cfm?abstract_id $=287652$

García, O. and Gill, B. (2005). El gobierno corporativo y las prácticas de earnings management: Evidencia empírica en España. Working Paper of Instituto Valenciano de Investigaciones Económicas (Ivie), WP-EC 11.

Gaver, J. and Gaver, K. (1993). Additional evidence on the association between the investment opportunity set and corporate financing, dividend, and compensation policies. Journal of Accounting and Economics, 16(1-3), 125-160.

Gomez-Mejia, L., Nuñez-Nickel, M., and Gutierrez, I. (2001). The role of family ties in agency contracts. Academy of Management Journal, 44, 81-95.

Gompers, P.A., Ishii, J.L., and Metrick, A. (2003). Corporate governance and equity prices. The Quarterly Journal of Economics, 118, 107-155.

Gopalan, R. and Jayaraman, S. (2011). Private Control benefits and earnings management: Evidence from insider controlled firms. Journal of Accounting Research, forthcoming.

Grossman, S.J. and Hart, O.D. (1982). Corporate financial structure and managerial incentives. In: The Economics of Information and Uncertainty. Ed. by J.J. McCall, Chicago: The University of Chicago Press, 123-155.

Harris, M. and Raviv, A. (1991). The theory of capital structure. Journal of Finance, 46, 297-356.

Hart, O. (1995). Firms, contracts, and financial structure. Oxford University Press, Oxford. Husted, B. and Serrano, C. (2002). Corporate Governance in México. Journal of Business Ethics, 37(3), 337-348.

Jara-Bertin, M. and López-Iturriaga, F.J. (2008). Earnings management and contest to the control: An analysis of european family firms. MPRA Paper No. 9660, posted 21. Retrieved from http://mpra.ub.uni-muenchen.de/9660/

Jensen, M.C. and Meckling, W.H. (1976). Theory of the firm: Managerial behavior, agency costs and ownership structure. Journal of Financial of Economics, 76, 305360.

Jensen, M.C. (1986). Agency costs and free cash flow, corporate finance, and takeovers. The American Economic Review, 76, 323-29. 
Jensen, M.C. and Murphy, K.J. (1990). Performance pay out and top management incentives. Journal of Political Economy, 98, 225-264.

Jensen, M.C. (1993). The modern industrial revolution, exit, and the failure of internal control systems. Journal of Finance, 48(3), 831-880.

Jones, J. (1991). Earnings management during import relief investigations. Journal of Accounting Research, 29, 193-233.

Khanna, T. and Palepu, K. (1999). Policy shocks, market intermediaries, and corporate strategy: Evidence from Chile and India. Journal of Economics and Management Strategy, 8, 271-310.

Lang, L., Ofek, E. And Stulz, R.M. (1996). Leverage, investment, and firm growth. Journal of Financial Economics, 40, 3-29.

La Porta, R., López-de-Silanes, F., Shleifer, A. and Vishny, R. (1997). Legal determinants of external finance. The Journal of Finance, LII (3), 1131-50.

La Porta, R., López-de-Silanes, F., Shleifer, A. and Vishny, R. (1998). Law and finance. Journal of Political Economy, 52(3), 1113-55.

La Porta, R., López-de-Silanes, F., Shleifer, A. and Vishny, R. (1999). Corporate governance around the world. Journal of Finance, 24, 471-517.

La Porta, R., López-de-Silanes, F., Shleifer, A. and Vishny, R. (2000). Investor protection and corporate governance. Journal of Financial Economics, 58, 3-27.

La Porta, R., López-de-Silanes, F., Shleifer, A. and Vishny, R. (2002). Investor protection and corporate valuation. Journal of Finance, 57 (3), 1147-70.

Lang, L. and Stulz, R. M. (1994). Tobin's q, corporate diversification, and firm performance. Journal of Political Economy, 102(6), 1248-80.

Lasfer, M.A. (1995). Agency costs, taxes, and debt: the UK evidence. European Financial Management, 1(3), 265-85.

Lemmon, M. and Lins, K. (2003). Ownership structure, corporate governance, and firm value: Evidence from the East Asian financial crisis. Journal of Finance, 58, 14451468.

Leuz, C., Nanda, D. and Wysocki, P.D. (2002). Investor protection and earnings management: and international comparison. Working Paper 4225-01, MIT Sloan School of Management.

Leuz, C., Lins, K. and Warnock, F. (2009). Do foreigners invest less in poorly governed firms? Review of Financial Studies, 22(8), 3245-3285.

Lins, K.V. (2003). Equity ownership and firm value in emerging markets. Journal of Financial and Quantitative Analysis, 38(1), 159-184.

López, F.J. and Lima, V. (2010). Do Leverage, Dividend Payout, and Ownership Concentration Influence Firms' Value Creation? An Analysis of Brazilian Firms. Emerging Markets Finance and Trade, 46(3), 80-94.

Lorsch, J. and Maclver, E. (1989). Pawns and potentates: The reality of corporate boards. Boston: Harvard Business School. 
Mak, Y.T. and Kusnadi, Y. (2005). Size really matters: Further evidence on the negative relationship between board size and firm value. Pacific-Basin Finance Journal, 13(3), 301-318.

Myers, S.C. (1977). Determinants of corporate borrowing. Journal of Financial Economics, 5, 147-175.

Mayer, C. (1996). Corporate governance, competition and performance. Journal of Law and Society, 24, 152-76.

McConaughy, D., Matthews, C. and Fialko, A. (2001). Founding family controlled firms: Performance, risk and value. Journal of Small Business Management, 39, 31-49.

McConnell, J. J. and Servaes, H. (1995). Equity ownership and the two faces of debt. Journal of Financial Economics, 39, 131-57.

Morck, R., Schleifer, A. and Visnhy, R. N. (1988). Management ownership and market valuation. Journal of Financial Economics, 20(1/2), 293-315.

Mohd.-Saleh, N., Mohd.-Iskandar, T. and Mohid-Rahmat, M. (2007). Audit committee characteristics and earnings management: evidence from Malaysia. Asian Review of Accounting, 15(2), 147-163.

Pound, J. (1988). Proxy contests and the efficiency of shareholder oversight. Journal of Financial Economics, 22, 237-265.

Rajan, R.G. and Zingales, L. (1995). What do we know about capital structure? some evidence from international data. Journal of Finance, 50(5), 1421-1460.

Roe, M.J. (2000). Political Foundations for Separating Ownership from Corporate Control. Stanford Law Review, 53.

San Martín-Reyna, J.M. (2010). Mecanismos de gobierno y protección al inversor como forma de control de la discrecionalidad directiva: Un estudio para países europeos", Innovar Journal, 20(37), 75-89.

San Martín Reyna, J. M. and Duran-Encalada, J. A. (2012). Relationship among family business, corporate governance and firm performance: Evidence from the Mexican stock exchange. Journal of Family Business Strategy, 3(2), 106-117.

Shackelford, D. (1998). Discussion of The effects of taxes, agency costs, and information asymmetry on earnings management: A comparison of public and private firms. Review of Accounting Studies, 3, 327-329.

Shleifer, A. and Vishny, R.W. (1997). A survey of corporate governance. The Journal of Finance, LII (2), 737-83.

Singh, M. and Faircloth, S. (2005). The impact of corporate debt on long term investment and firm performance. Applied Economics, 37, 875-883.

Skinner, D. (1993). The investment opportunity set and accounting procedure choice. Journal of Accounting and Economics and Economics, 16, 407-445.

Smith, C. W. and Watts, R. (1992). The investment opportunity set and corporate financing, dividend, and compensation policies. Journal of Financial Economics, 32, 263-92.

Stiglitz, J.E. (1985). Credit markets and the control of capital. Journal of Money Credit and Banking, 17, 133-152. 
Stulz, R. (1990). Managerial discretion and optimal financing policies. Journal of Financial Economics, 26, 3-27.

Wang, D. (2006). Founding family ownership and earnings quality. Journal of Accounting Research, 44(3), 619-656.

Warfield, T.D., Wild, J.J. and Wild, K.L. (1995). Managerial ownership, accounting choices, and informativeness of earnings. Journal of Accounting and Economics, 16, 61-91.

Watts, R.L. and Zimmerman, J.L. (1986). Positive accounting theory. Prentice Hall, Englewood Cliffs.

Yermarck, D. (1996). Higher market valuation of companies with a small board of directors. Journal of Financial Economics, 40, 185-211.

\begin{abstract}
Polish)
Praca analizuje wpływ struktury własności, rady nadzorczej i dźwigni finansowej na zarzqdzanie zyskiem w sytuacjach, gdy przedsiębiorstwo staje wobec możliwości rentownego rozwoju i gdy taka możliwość nie istnieje. Badanie jest oparte o próbę 83 meksykańskich firm idotyczyokresu 2005-2011. Rezultaty wskazujqna pozytywnyzwiqzek zachodzq̨y pomiędzy zarzq̨dzaniem zyskiem i radq nadzorczq oraz dźwigniq finansowq w sytuacji możliwości rozwoju firmy. Zwiqzek ten ma charakter ujemny, gdy firma nie ma możliwości podjęcia rentownych projektów inwestycyjnych. Rezultaty wskazujq także na znaczenie kontroli udziałowców firmy na zarzqdzanie zyskiem w sytuacji potencjalnego wzrostu. W podsumowaniu, struktura własności, skład i wielkość rady oraz dźwignia finansowa redukujq zarzq̨dzanie zyskiem w sytuacji braku możliwości podjęcia projektów inwestycyjnych i majq dodatni wpływ, gdy takie możliwości pojawiaja się.
\end{abstract}

Słowa kluczowe: dźwignia finansowa, możliwości inwestycyjne, biznes rodzinny. 